\title{
Food Sovereignty and Fome Zero: Connecting Public Food Procurement Programmes to Sustainable Rural Development in Brazil
}

\author{
HANNAH WITTMAN AND JENNIFER BLESH
}

\begin{abstract}
The global discourse on food sovereignty suggests several mechanisms for improving food security and agricultural livelihoods, including redistributive land reform and restructuring of markets to improve food distribution and access. In Brazil, the Fome Zero (Zero Hunger) social welfare programme has created innovative links between public nutrition and food security programmes and rural development initiatives through mediated market support for the family farm sector. We report on a participatory assessment of the experience of land reform beneficiaries in seven municipalities in Mato Grosso, Brazil, who were contracted to produce food for the Programa de Aquisição de Alimentos (Food Procurement Programme, PAA) and the Programa Nacional de Alimentação Escolar (National School Feeding Programme, PNAE) under the umbrella of Fome Zero. This analysis offers insight into the opportunities and challenges related to participation in mediated 'farm-to-institution' food procurement programmes, and assesses their influence on key food sovereignty principles, including agro-ecological transition, increased market stability and farmer autonomy.
\end{abstract}

Keywords: food sovereignty, public procurement, home-grown school feeding, agro-ecology, agrarian reform

\section{INTRODUCTION}

Volatile global food prices, environmental degradation in agricultural systems and the combined crises of poverty and malnutrition have reinvigorated debates about the distinct and overlapping roles of government, civil society and divergent agricultural production models in addressing the complex and systemic problems related to both household food insecurity and overall food-system sustainability (Lang et al. 2009; Lang 2010; de Schutter 2010; Sonnino et al. 2014). In response, the global food sovereignty movement has advocated for food-system restructuring involving grassroots mobilization for an alternative agrarianism coupled with new forms of state support for domestic food and agricultural sectors (Wittman 2011; McKay et al. 2014; McMichael 2014; Jansen 2015). While the discourses under the food sovereignty umbrella are wide-ranging (and sometimes contradictory) (Hospes 2013; Chaifetz and Jagger

\footnotetext{
Hannah Wittman, University of British Columbia, Faculty of Land and Food Systems, Institute for Resources, Environment and Sustainability, Vancouver, BC, Canada V6T 1Z4. E-mail: hannah.wittman@ubc.ca. Jennifer Blesh, University of Michigan, School of Natural Resources and Environment, 440 Church Street, Ann Arbor, MI 48109, USA. E-mail: jblesh@umich.edu

We are grateful for helpful comments from the peer reviewers and feedback and/or research assistance from Sarah Anton, Bernardo Mançano Fernandes, Johan Oldekop, Patricia Mesquita, Sophia Murphy, Brooke Pian and Winie Vasconcelos. Funding was provided by the National Science Foundation (Award \#1064807) and the Social Sciences and Humanities Research Council of Canada.
} 
2014), a common definition involves food sovereignty as 'the right of peoples to healthy and culturally appropriate food produced through ecologically sound and sustainable methods, and their right to define their own food and agriculture systems' (Nyéléni Forum for Food Sovereignty 2007). Many of these discourses and definitions build on the common challenges in linking the right to food - especially for the urban poor - to the right to produce food in rural and agricultural economies using fair, sustainable and equitable models of food production and distribution (Anderson 2008; de Schutter 2010; Wittman 2011; Hospes 2013). Common principles of food sovereignty frameworks articulated by movements and initiatives across the globe include ensuring the right to food, improving opportunities for citizen engagement in food-system restructuring, ensuring adequate livelihoods for food providers and improving environmental sustainability through a transition to agro-ecological production practices (cf. Windfuhr and Jonsén 2005; Nyéléni Forum for Food Sovereignty 2007; Patel 2009; Martinez-Torres and Rosset 2010).

The mechanisms for achieving these goals and principles in a given context, however, are widely contested as to their potential, and in many cases lack operationalization. Since the mid-1990s, food sovereignty advocates have emphasized the need for renewed public support for domestic agricultural economies, especially after the dismantling of national food reserves, price supports and targeted agricultural credit and extension programmes following the implementation of the 1995 Agreement on Agriculture (McMichael 2003). Structural adjustment programmes also reduced support for diversified national agricultural sectors, in favour of a food security logic of external dependency based on international agricultural trade (Otero et al. 2013).

Given the negative effects of trade liberalization on farmers' livelihood strategies, especially in developing countries (McMichael 2003; Rosset 2006; Bello 2008, 2009), and the ongoing challenges of achieving global and regional food security, some governments and movements now advocate for food-system localization - either at the national or regional scale - as an economic development strategy. The discourse of food sovereignty as an objective related to national self-sufficiency is explicitly utilized in some national legislation (i.e. in Indonesia and Venezuela, which are net food importers for staple foods). In contrast, other legislative frameworks define food sovereignty more broadly as a goal to strengthen domestic agricultural systems (e.g. Bolivia), or to support rural development and fair market conditions, particularly for the family farm sector (e.g. Brazil). Increasingly, food sovereignty initiatives rely on state involvement in establishing 'institutional, infrastructural, and legal supports and protections' (McKay et al. 2014, 1176) for national agricultural sectors, with a recognition of the distinct needs in these areas for different agricultural classes and domains.

\section{Mediated Markets: A Pathway to Food Sovereignty?}

Across the literature, the conditions perceived as necessary to engender food sovereignty involve restructuring access to land, food, and markets not only for food providers, but also for consumers. Redistributive land reform is designed to improve access for the rural poor to productive resources, often designed as a rural economic development strategy to bring 'unproductive' lands into the market (Wolford 2007; Borras and Franco 2010a,b). Restructuring markets to increase or change the composition of agricultural production, and to improve distribution and access to food itself, can involve reducing food prices through price supports to producers, the installation of food reserves, and public procurement and social safety net programmes such as food banks, school feeding programmes, conditional cash-transfer programmes and government regulation of food prices (de Schutter 2010, 2011a, 2014; Sidaner 
et al. 2013; Sonnino et al. 2014). Targeted public procurement programmes are a form of mediated market designed to make trade more 'socially efficient' through government facilitation of trade relationships, particularly in the area of the provision of food security and other basic social welfare needs (Rocha 2007). Many governments use forms of social market infrastructure for public nutrition as a social protection response in the face of food and fuel crises (Gentilini and Omamo 2011). For example, the UN World Food Programme, which assists 22 million children with school feeding in 70 countries, has increasingly moved towards a public procurement model that they call 'Purchasing for Progress', or P4P, that experiments with ways to buy staple food and promote marketing opportunities for local farming communities. The P4P has now been piloted in 21 countries with 500,000 smallholder farmers. ${ }^{1}$ More broadly, Home-Grown School Feeding programmes (HGSF) have emerged as an opportunity to support rural sustainable development and meet food security and educational challenges by facilitating social and economic relations between targeted populations of producers and consumers (Bagdonis et al. 2008; Rocha 2009; Otsuki 2011; Sumberg and Sabates-Wheeler 2011; Buckley et al. 2013; Quaye et al. 2013; Sonnino 2013). As part of a 'systems' approach to food security, mediated markets involving targeted food procurement and distribution aim to address the structural determinants of food security through a reduction in food price volatility (a challenge for both urban consumers and rural producers) and the maintenance of vibrant domestic food supply chains (Ashe and Sonnino 2013).

A growing body of work on food-system localization and alternative food networks in North America and Europe examines primarily civil society-driven initiatives to increase the share of local food procured by institutional food programmes, particularly schools (Kirwan and Foster 2007; Joshi et al. 2008; Gottlieb et al. 2009; Conner et al. 2010, 2011; Buckley et al. 2013). This body of work focuses on changes in student dietary behaviours, food literacy and changes in food service and menu composition (Joshi et al. 2008), the social networks for 'civic agriculture' that aim to garner support from urban markets for revitalizing rural communities (Bagdonis et al. 2008; Buckley et al. 2013), and farmer motivations for participating in farm-to-institution markets (Joshi et al. 2008; Izumi et al. 2010; Thompson et al. 2014; Matts et al. 2015). Globally, the assessment of targeted food procurement programmes has focused primarily on child nutrition and educational attainment through regular access to healthy and nutritious foods in the school context (Bundy et al. 2009, 2013; Bundy 2011; Alderman and Bundy 2012). Devereux et al. (2010) suggest that appropriately designed and implemented HGSF programmes have the potential to reduce poverty and foster local economic growth. Some HGSF programmes aim to stabilize local food prices, attenuate marketing risks and facilitate access to credit, training and technology (Finan et al. 2010, 1; Sumberg and Sabates-Wheeler 2011; Masset and Gelli 2013). For example, Espejo et al. (2009) argue that investment in agricultural production strategies for target markets such as school feeding programmes can facilitate increased productivity through increased market access, betterquality crops, the adoption of new technologies and risk mitigation for small-scale farmers. Finally, de Schutter $(2014$, 3) notes that effective public procurement schemes in the food sector should 'target vulnerable groups; support food accessibility and adequate diets; ensure environmental sustainability; and include participation, accountability and empowerment'.

Despite the global wave of policy and programming in this area, and extensive evaluation of the impact on consumer beneficiaries, little empirical assessment has been conducted on

1 See http://www.wfp.org/purchase-progress (accessed 29 July 2015).

(C) 2015 John Wiley \& Sons Ltd 
the impacts of increased and/or targeted public procurement of local food on the livelihoods and farm management strategies of regional food producers who are targeted to supply such programmes (for a Ghana case study, see Quaye et al. 2009, 2013). Additionally, almost no work focuses on programmes where targeted public procurement has been implemented as formal state policy (as opposed to voluntary or civil society-led initiatives). In this paper, we focus on the case of land reform beneficiaries in Mato Grosso, Brazil, who are contracted to produce food for the Programa de Aquisicão de Alimentos (Food Procurement Programme, PAA) and the Programa Nacional de Alimentacão Escolar (National School Feeding Programme, PNAE) under the umbrella of Brazil's landmark Fome Zero (Zero Hunger) social welfare programme. Our analysis offers insight into the potential of public food procurement programmes such as the PAA and PNAE to simultaneously address food security and rural development goals, and assesses the extent to which they can serve as an enabling mechanism for the achievement of food sovereignty. This paper draws from ethnographic and household survey research conducted in agrarian reform settlements in seven municipalities in the central Brazilian state of Mato Grosso between 2003-6 and 2012-13.

We begin with an overview of the policy environment for public nutrition and rural development in Brazil, which became more explicitly integrated in 2003 under the Fome Zero platform of the Worker's Party government. We then present our methodological approach and results from a participatory assessment of programme implementation from the perspectives of the target beneficiaries, family farmers in agrarian reform settlements in central Brazil. We conclude by analysing the challenges and limitations of public food procurement programmes in terms of their contributions to food sovereignty and rural development.

\section{FOME ZERO AND FAMILY FARMING IN BRAZIL}

Brazil's Fome Zero programme has its roots in mid-century social reform policy, starting with the creation of the first National Food Commission in 1945 and the implementation of a national school meal programme in 1955 under the Ministry of Education (CNSAN 2010). Between 1962 and 1990, the government developed several public programmes related to hunger and nutrition (Pronan I and II - the National Food and Nutritional Programme, 1973 and 1976; ENDEF - the National Study on Family Spending, 1974; PAT - the Workers Food Programme, 1976; and the PNSN - the National Research Framework for Health and Nutrition, 1989).

During the same period, Brazil began an agrarian transition that saw the modernization of the countryside and an increasing investment in large-scale and export-oriented agriculture (Fernandes et al. 2012). Displaced family farmers participated in colonization programmes at the agrarian frontier, and social movements including the Landless Workers Movement (MST) began mobilizing for government support for the family farm sector in the early 1980s (Wolford 2010). Land distribution, often in remote and degraded agricultural areas, became a key initiative to quell rural unrest, with 933,000 families receiving parcels in 9,000 land reform settlements covering 81 million hectares across the country between 1973 and 2012 (DATALUTA 2012).

The family farm sector in Brazil, defined by small-scale landholdings using primarily family labour, includes 4.37 million farms ( $84 \%$ of all holdings on $24.3 \%$ of the total agricultural area) (IBGE 2009). While the non-family farm sector focuses on export-oriented crops (primarily soybean, sugar cane, beef and oranges), Brazil's family farmers are primarily oriented to cultivation for domestic consumption. The 2006 national agricultural census estimated that family farmers produce 70 per cent of the total domestic food consumption on 
less than 25 per cent of the agricultural land ( $87 \%$ of cassava, $70 \%$ of dry beans, $59 \%$ of pork, $58 \%$ of milk, $50 \%$ of poultry, $46 \%$ of corn, $38 \%$ of coffee, $34 \%$ of rice and $30 \%$ of beef: de França et al. 2009; Fernandes 2014).

Despite the important role of the family farm sector in terms of GDP, rural employment and food production for domestic consumption, it receives significantly lower levels of government support when compared to the export-oriented agribusiness sector. Brazil is the only country in the world with two distinct federal ministries related to agricultural production. The Ministry of Agriculture's 2013-14 budget of R136 billion (US $\$ 62$ billion) provides targeted support for the agribusiness sector in the form of low-interest loans, grants and capital investment projects (MAPA 2013). The Ministry of Agrarian Development (Ministério de Desenvolvimento Agrário, MDA) was created in 1999 and is charged with supporting the family farm sector. The MDA now also oversees the National Programme for Strengthening Family Agriculture (PRONAF), a specialized regime of agricultural credit that was created in 1996 to support the family farm sector (de Arruda Saron and Hespanhol 2012). For the 2013-14 season, the MDA budgeted R39 billion (US\$17.8 billion) for operating loans, crop insurance, agricultural extension, home-grown school feeding and other public nutrition programmes (MDA 2013).

In the 1990s, rural and urban social movements began a joint campaign to demand government action to address growing levels of hunger and malnutrition (Schneider et al. 2010; Mendoça Leão 2012; Rocha et al. 2012). The National Council on Food Security (CONSEA) was established in 1993 as an advisory body for the federal government, with the participation of ten ministers and 21 collaborators from civil society. Although CONSEA was inactive from 1994 to 2003 (Medaets et al. 2004), a National Forum on Food and Nutritional Security was formed in 1998 by government, social organizations and research organizations building on public consultations around food security leading up to the 1996 World Food Summit in Rome.

In 2001, Brazil's Citizenship Institute released a campaign entitled the Zero Hunger Project. This platform became a key campaign pillar leading up to the election of Luiz Ignacio Lula da Silva in 2002, and to the formal launch of the Fome Zero programme and the re-establishment of CONSEA in 2003 (Rocha 2009; Chmielewska 2011). Fome Zero consolidated a series of existing social welfare and development policies, while adding new programmes and creating new strategies to address social welfare across Brazil's diverse social contexts. The Fome Zero platform was organized around four main pillars: access to food, strengthening family farming, income generation and social articulation, mobilization and control. 'Structural Policies' included job and income generation, universal social security, conditional cash-transfer programmes and minimum wage increases (da Silva et al. 2011). Agrarian reform and supports to the family farm sector, formerly governed separately in federal land distribution agencies and in the MDA, moved under the Fome Zero umbrella, and several new policies and programmes began to specifically focus on changing the dynamics of food production and distribution in the country. Between 2003 and 2009, Fome Zero contributed to bringing 20 million people out of extreme poverty in Brazil, increasing the income of family farmers by 33 per cent, and increasing the participation of civil society in construction of a new dialogue around the right to food (da Silva et al. 2011). During this period, the incidence of national food insecurity was reduced from 34.8 per cent to 30.5 per cent (Sidaner et al. 2013).

The expanded dialogue around the Fome Zero platform has included a new consideration of the right to food and food sovereignty within the Brazilian policy context. In 2006, CONSEA initiated the legislation of a National Law on Food and Nutrition Security 
(LOSAN), where the right to food became an obligation of the state and transformed CONSEA into a permanent institution (Law 11.346). The law states:

the realization of the human right to adequate food and to food and nutritional security requires respect for sovereignty, that confer on countries the primacy of their decisions around the production and consumption of food. (Republic of Brazil, 2006)

By 2010, Brazil had amended its constitution to include the right to food as a basic human right and passed a decree extending the reach of the 2006 Food Security Law to directly engage with changing agricultural conditions for the family farm sector. It calls for public support for:

promoting sustainable agro-ecological systems for producing and distributing food, that respect biodiversity and strengthen family agriculture, indigenous peoples, and traditional communities that ensure the consumption and access to adequate and healthy food, respecting the diversity of national food cultures ... incorporating into State policy respect for food sovereignty and the human right to adequate food. (Decree 7272, Republic of Brazil, 2010)

\section{PAA AND PNAE: LINKING PUBLIC NUTRITION TO THE FAMILY FARM SECTOR THROUGH MEDIATED MARKETS}

In this paper, we focus on one particular innovation within the Fome Zero platform, the explicit connection between public nutrition programmes and investment in the family farm sector, which had been neglected in Brazil's agricultural modernization strategy throughout the 1980s and 1990s (Rocha et al. 2012). This initiative builds on increasing interest at the global level in linking economic development and income growth policies with social protection initiatives to leverage 'win-win solutions' (Espejo et al. 2009; Otsuki 2011; Sumberg and Sabates-Wheeler 2011; Otsuki 2014). For example, Dorward (2013) discusses a model whereby investment in new technologies and resources for labour productivity can foster economic and social development outcomes.

In Brazil, the federal Food Acquisition Program (PAA) was launched in 2003 to increase food and nutritional security, contribute to public food stocks for price regulation and use in government food programmes, to provide market space for family farmers and to strengthen the position of the family farm sector (CONAB 2006; Grisa et al. 2011). The implementation of PAA was a response to the call to address food insecurity at the national level, and to recognize the need to support family farmers as a social category in public policies. The PAA aimed to secure a source of income for small-scale farmers, ensure a price floor and increase marketing capacity, while also increasing public food stocks for public nutrition programmes, particularly in schools and other social service centres (Peraci and Bittencourt 2011). By providing incentives (including price premiums and targeted agricultural extension programmes for agro-ecological and organic production), the PAA also sought to leverage a shift towards more sustainable production practices (Grisa et al. 2011).

The PAA is principally funded and managed by the Ministry of Social Development, with complementary funding and support from the Ministry of Agrarian Development for agricultural credit and extension programmes. Although a legislative change in 2012 allowed a wider range of sales options for individual growers, the majority of programmes within the PAA require farmers to belong to an association or a cooperative. Producers enter into a contract with the National Food Supply Company (CONAB), which mandates a regional pricing 
Table 1. The total PAA budget in Brazilian currency ( $\$$ )

\begin{tabular}{|c|c|c|c|c|c|}
\hline \multirow[t]{2}{*}{ Year } & \multirow{2}{*}{$\begin{array}{c}\text { Brazil } \\
\text { Reais }(R \$)\end{array}$} & \multicolumn{2}{|c|}{ Mato Grosso (MT) } & \multicolumn{2}{|c|}{ Study municipalities $(N=7)$} \\
\hline & & Reais $(R \$)$ & $\begin{array}{c}\text { Percentage of } \\
\text { Brazilian budget }\end{array}$ & Reais $(R \$)$ & $\begin{array}{l}\text { Percentage of } \\
M T \text { budget }\end{array}$ \\
\hline 2003 & $81,541,207$ & $1,757,588$ & 2.2 & - & \\
\hline 2004 & $107,185,826$ & 262,588 & 0.2 & - & \\
\hline 2005 & $112,791,760$ & $2,851,090$ & 2.5 & - & \\
\hline 2006 & $200,667,300$ & $2,997,800$ & 1.5 & - & \\
\hline 2007 & $214,790,990$ & $4,887,860$ & 2.3 & $1,318,748$ & 27.0 \\
\hline 2008 & $272,490,390$ & $5,982,860$ & 2.2 & 780,457 & 13.0 \\
\hline 2009 & $363,381,941$ & $4,587,963$ & 1.3 & 622,996 & 13.6 \\
\hline 2010 & $379,735,466$ & $10,448,230$ & 2.8 & $1,567,782$ & 15.0 \\
\hline 2011 & $451,036,204$ & $12,379,561$ & 2.7 & $2,070,711$ & 16.7 \\
\hline 2012 & $586,567,131$ & $19,496,757$ & 3.3 & $1,862,440$ & 9.6 \\
\hline Totals & $2,770,188,216$ & $65,652,297$ & & $8,223,134$ & \\
\hline
\end{tabular}

Source: CONAB Annual Reports, 2003-12; CONAB-MT Annual Reports, 2006-12.

structure based on the estimated cost of production for the family agriculture sector, taking into consideration input prices such as seeds and fertilizers. Annual contracts were initially capped at $\mathrm{R} \$ 2,500$ per farmer in 2003 (at that time, about ten times the monthly minimum wage). In 2013, the ceiling was increased to $\mathrm{R} \$ 5,500$ for individual families and $\mathrm{R} \$ 6,500$ for members of cooperatives. The cap increased to $\mathrm{R} \$ 8,000$ for products that are certified as organic, agro-ecological or as fulfilling the criteria of 'socio-biodiversity' (MDA 2013). Tables 1-4 describe the total budget, the number of farmer participants, the number of beneficiaries and the volume of food purchased through the PAA from 2003 to 2012.

At the federal level, the PAA Managing Group is coordinated by the Ministry of Social Development and includes representatives from the Ministry of Planning, the Ministry of Agrarian Development, the Ministry of Agriculture, the Ministry of Finance and the Ministry of Education. Municipal governments play a coordinating role in product placement, and occasionally provide transportation and packing facilities to farmer associations. Products marketed through the PAA are delivered as part of municipal public nutrition programmes in public schools, youth programmes and community centres, hospitals, day-care centres, food banks and 'subsidized restaurants' in low-income neighbourhoods. PAA implementation is monitored by municipal Food and Nutrition Security Councils or other municipal-level agencies such as Rural Development Councils or School Boards (Otsuki and Arce 2006; CONAB-MT, pers. comm., 2013).

As a second example of a mediated market for food security linked to rural development goals, Brazil's national school feeding programme (Programa Nacional de Alimentação Escolar, PNAE) provides a daily meal for 45 million students enrolled in public schools. In the context of the widespread policy shift in food and nutrition policy described above, the PNAE was significantly redesigned in 2009 to integrate 'education, agriculture, health and social protection to promote access to healthy diets at school while strengthening family farming' (Sidaner et al. 2013). While poverty alleviation is not an explicit goal of the PNAE, the passage of a national School Feeding Law in 2009 (Law 11.947) set the stage for several key shifts in school feeding programmes affecting the family farm sector: revised nutritional 
Table 2. PAA farmer participants, 2003-12

\begin{tabular}{|c|c|c|c|c|c|c|}
\hline \multirow[t]{2}{*}{ Year } & \multicolumn{2}{|c|}{ Brazil } & \multicolumn{2}{|c|}{ Mato Grosso } & \multicolumn{2}{|c|}{ Study municipalities $(N=7)$} \\
\hline & Number & $\begin{array}{l}\text { Percentage of } \\
\text { family farms }\end{array}$ & Number & $\begin{array}{l}\text { Percentage of } \\
\text { family farms }^{a}\end{array}$ & Number & $\begin{array}{l}\text { Percentage of } \\
\text { family farms }\end{array}$ \\
\hline 2003 & 41,341 & & 865 & & - & \\
\hline 2004 & 49,671 & & 144 & & - & \\
\hline 2005 & 51,975 & & 1,482 & & - & \\
\hline 2006 & 86,543 & 1.90 & 1,437 & 1.60 & 130 & 2.25 \\
\hline 2007 & 92,372 & 2.03 & 1,764 & 1.96 & 376 & 6.50 \\
\hline 2008 & 90,634 & 1.99 & 1,961 & 2.18 & 418 & 7.23 \\
\hline 2009 & 98,340 & 2.16 & 1,556 & 1.73 & 199 & 3.44 \\
\hline 2010 & 94,398 & 2.07 & 3,033 & 3.37 & 427 & 7.38 \\
\hline 2011 & 106,600 & 2.34 & 3,006 & 3.34 & 486 & 8.40 \\
\hline 2012 & 128,804 & 2.83 & 4,587 & 5.10 & 488 & 8.44 \\
\hline Totals & 840,678 & & 19,835 & & 2,524 & \\
\hline
\end{tabular}

Source: CONAB Annual Reports, 2003-12; CONAB-MT Annual Reports, 2006-12; IBGE 2006 Agricultural Census.

a IBGE Agricultural Census data for 2006 to calculate the percentage of participating family farmers.

Table 3. PAA beneficiaries: people and institutions

\begin{tabular}{|c|c|c|c|c|c|c|}
\hline \multirow[t]{2}{*}{ Year } & \multicolumn{2}{|c|}{ Brazil } & \multicolumn{2}{|c|}{ Mato Grosso } & \multicolumn{2}{|c|}{ Study Municipalities $(N=7)$} \\
\hline & People & Institutions & People & Institutions & People & Institutions \\
\hline 2003 & $2,569,459$ & 776 & & - & - & - \\
\hline 2004 & 541,070 & 374 & - & - & - & - \\
\hline 2005 & $2,079,937$ & - & 9,972 & - & - & - \\
\hline 2006 & $4,290,986$ & - & 66,549 & - & 16,499 & 41 \\
\hline 2007 & $7,915,373$ & 13,611 & 144,114 & 440 & 34,040 & 188 \\
\hline 2008 & $10,525,333$ & 17,713 & 210,239 & 588 & - & 112 \\
\hline 2009 & $8,129,258$ & 11,548 & 66,527 & 226 & 19,365 & 45 \\
\hline 2010 & $14,292,020$ & 17,754 & 419,217 & 915 & 53,486 & 141 \\
\hline 2011 & $16,290,738$ & 17,722 & 418,507 & 750 & 52,413 & 266 \\
\hline 2012 & $18,208,960$ & 17,988 & 461,835 & 882 & 32,775 & 41 \\
\hline Total & $84,843,134$ & 97,486 & $1,796,960$ & 3,801 & 208,578 & 834 \\
\hline
\end{tabular}

Source: CONAB Annual Reports, 2003-2012; CONAB-MT Annual Reports 2006-2012.

guidelines set menu composition standards that prioritized traditional and regionally adapted eating preferences, set a mandatory inclusion of fresh fruits and vegetables, and restricted the use of processed foods with high levels of sodium and fat. Most significantly, 30 per cent of the PNAE budget is now legally directed to be used to obtain food from the local family farm sector, with priority given to foods produced using organic or agro-ecological methods (Sidaner et al. 2013). Although the overall proportion of schools purchasing some foods from the family farm sector has increased from 48 per cent to 67 per cent between 2010 and 2012, 
Table 4. Tons of food acquired, PAA programmes

\begin{tabular}{lrcc}
\hline Year & Brazil & Mato Grosso & $\begin{array}{r}\text { Study municipalities } \\
(\mathrm{N}=7)\end{array}$ \\
\hline 2003 & 135,244 & 4,507 & - \\
2004 & 156,972 & 337 & - \\
2005 & 118,664 & 7,248 & - \\
2006 & 212,193 & 5,979 & 467 \\
2007 & 189,978 & 6,450 & 489 \\
2008 & 234,908 & 4,030 & 421 \\
2009 & 287,174 & 5,226 & 1,088 \\
2010 & 225,895 & 6,322 & 1,322 \\
2011 & 285,641 & 7,325 & 934 \\
2012 & 297,610 & 10,452 & 4,893 \\
Totals & $2,144,280$ & 57,875 & \\
\hline
\end{tabular}

Source: CONAB Annual Reports, 2003-12; CONAB-MT Annual Reports, 2006-12.

many are failing to meet the 30 per cent target (Soares et al. 2013). For 2013/14, the PNAE budget for targeted procurement from the family farm sector reached $\mathrm{R} \$ 1.1$ billion (MDA 2013).

The 2009 School Feeding Law initiated the organization of Municipal School Feeding Committees comprised of representatives from the municipal government, teachers, parents and local civil society (e.g. farmers' associations and NGOs). Each school district establishes the menu and product list, which must be approved by certified Ministry of Education nutritionists. Schools are then obligated to fulfil 30 per cent of their school lunch programme from local family farmers through two different target public procurement mechanisms, as follows: (a) They can receive a 'donation' from the PAA programme, where contacts are filled by participating family farm associations. In this case, the food costs do not come out of the school's budget. (b) They receive bids from individual farmers, farmer associations or cooperatives on PNAE contracts, and pay the market price for the products. The schools then fulfil the remainder of their food requirements from the open market, supermarkets or local distributors. In 2009, family farmer contracts in the targeted PNAE programme were capped at $\mathrm{R} \$ 9,000$, but they were increased to $\mathrm{R} \$ 20,000$ by 2012 . At a national level, a survey conducted by the PNAE indicated that school participation in the PAA programme has resulted in a significant increase in the offering of fruits and vegetables in school menus (in $2004,28 \%$ of school menus offered fruits and $57 \%$ offered vegetables, increasing to $62 \%$ and $80 \%$, respectively, in 2006). Schools receiving food rations through the PAA also reported increased food quality overall and a lower cost of delivering school feeding programmes (Sidaner et al. 2013).

\section{MEDIATED MARKETS IN MATO GROSSO: FOSTERING RURAL DEVELOPMENT FOR THE FAMILY FARM SECTOR?}

To gain a deeper understanding of how Brazil's agrarian development policies under the Fome Zero framework are implemented in a particular place, we conducted field research in the central Brazilian state of Mato Grosso (Figure 1), where the family farm sector struggles to 
Figure 1 (a) Mato Grosso, Brazil. (b) study municipalities

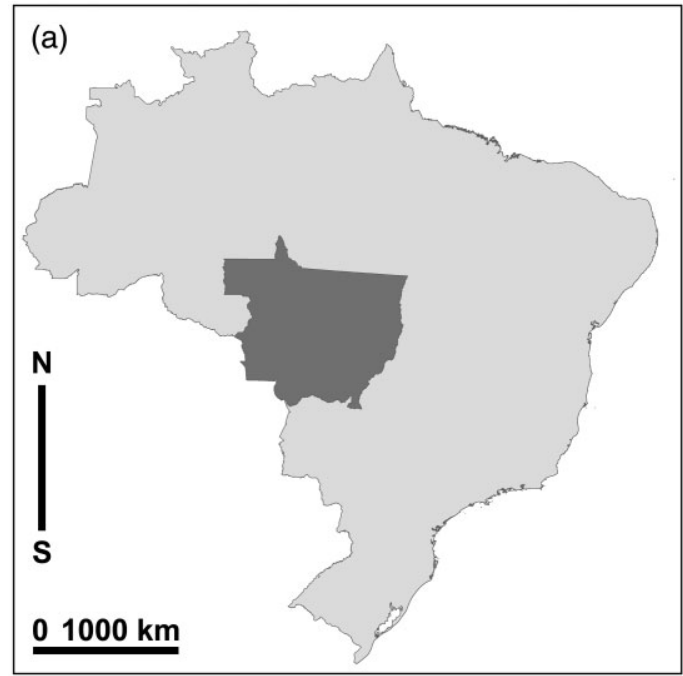

Brazil $\square$ Mato Grosso

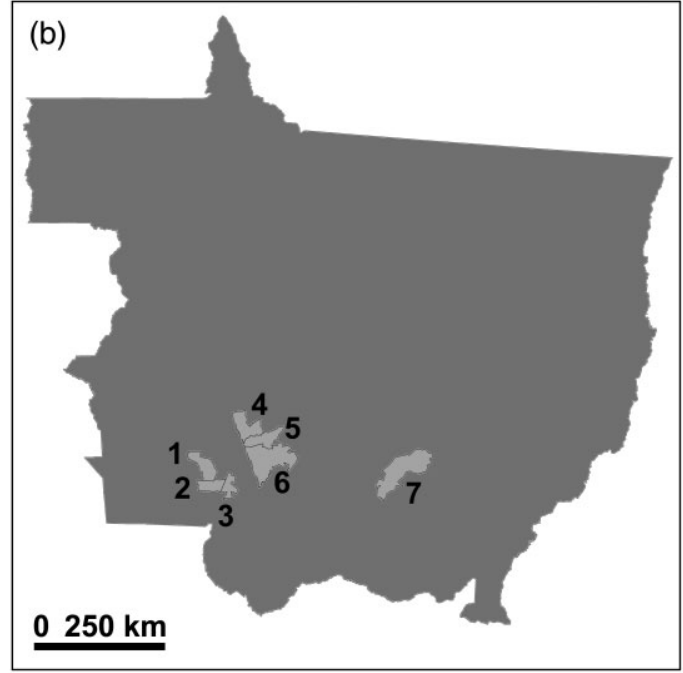

1. Araputanga 2. São Jose dos Quatro Marcos

3. Mirrasol D'Oeste 4. Tangará da Serra

5. Nova Olímpia 6. Barra do Bugres

7. Campo Verde

survive in the heart of Brazil's most vibrant agro-export zone (Blesh and Wittman, 2015). The agricultural frontier in Mato Grosso has long been a site of contention over land occupation between the family farm sector and agribusiness. Beginning in the late 1970s, land reform in Mato Grosso took the form of state and private colonization projects in remote forested areas at the agricultural frontier, following state and federal incentives to settle the area and provide labour for timber, ranching and modernized agriculture, as well as alleviating population pressures from south-east and north-east Brazil (Wittman 2009). These settlements, isolated from infrastructure, markets and public services, suffered from extreme deforestation, lack of agricultural extension, rapid degradation of agricultural plots and re-concentration of land, as multiple family plots were sold to individual ranchers. Attempts by international NGOs and state agencies to promote agroforestry programmes, while ongoing, have been slow to catch on, primarily due to lack of inputs, incentives and markets for non-timber forest products.

The soybean boom at the agricultural frontier in the sensitive Cerrado and Amazon transition zone in the northern half of the state began in the early 1990s. This transition was supported by significant public and private investment in infrastructure (roads and storage units), soil amendments and new seed varieties. Between 1990 and 2010, acreage in soybean cultivation increased six-fold, to 6.2 million hectares. The rapid advance of mechanization and agrochemical use, in addition to deforestation of the Cerrado and the introduction of foreign plant species, have transformed Mato Grosso's physical landscape. Desertification and groundwater and river contamination are rising due to the large-scale use of chemical fertilizers, desiccants and herbicides/pesticides, and soil compaction and erosion are also increasing concerns (Vieira and Galdino 2004). At the same time, only 45 per cent of crop calories in Brazil are directed to food for direct consumption (with $41 \%$ used as feed and $14 \%$ in 
biofuels). If oriented to human food consumption, Brazil's current level of agricultural production could feed 10.6 people per hectare, double its current capacity (Cassidy et al. 2013).

In Mato Grosso, 89,000 family farm establishments utilize 6.3 million hectares of agricultural land ( $80 \%$ of all farm establishments in MT on only $12 \%$ of the total agricultural land in the state) (IBGE 2009). Of these, almost 83,000 families have been settled on 539 agrarian reform settlements across the state between 1979 and 2011 (INCRA and MDA 2012). As an alternative to both the colonization model at the agricultural frontier and the expansion of the soybean economy, in 1995 the Rural Landless Workers Movement (MST) began to promote settlements in more populated municipalities near the state capital of Cuiabá. Between 1995 and 2012, the MST organized 42 settlements involving 4,250 families on 140,500 hectares of land. The MST has incorporated an explicit agro-ecological programme into its mobilization and strategies for agrarian reform. This includes the development of environmental education modules, extension in agro-ecological practices (including biocontrols for pests), implementation of common forest reserve areas, and collective resource development and planning. The MST has also used an alternative spatial layout within individual settlements by organizing plots in family nucleus arrangements to facilitate infrastructure provision, community building and mutual assistance (Wittman 2010).

Family farmers in land reform settlements are a primary target group for the PAA and PNAE procurement initiatives in Mato Grosso. The Director of the Mato Grosso branch of the National Institute for Colonization and Agrarian Reform (INCRA) indicated that PAA and PNAE participation is common across land reform beneficiaries across the state, and that the programme has been a primary motivation for the formation of cooperatives and marketing associations (interview, March 2013). However, our review of project participation data indicated that 4,587 family farms participated in the PAA programme in 2012 (Table 2), comprising just 5 per cent of the target population in Mato Grosso. A subjective evaluation of the PAA programme provided by a state-level government official in Mato Grosso indicates that the programme has had significant impacts on improving rural development conditions:

I know many families that had their lives changed by the PAA. They started with nothing, but now they have improved their houses, their transportation, and everything changed in their lives. (Interview, INCRA, 2013)

This positive assessment was echoed in qualitative interviews with many participants in our study, who cited the ability to market small quantities of products on a regular basis as an appreciable boost to their income. However, given the limited uptake in the family farm sector, we sought to unpack the opportunities and challenges to programme participation as a means of understanding the low levels of participation, and to assess the potential of mediated markets such as the PAA and PNAE to serve as pathways to food sovereignty and rural development.

\section{A PARTICIPATORY ASSESSMENT OF MEDIATED MARKETS IN MATO GROSSO}

Given the challenging social and biophysical context of family farming in Mato Grosso, we sought to understand the opportunities and barriers associated with participation in the PAA and PNAE programmes from the perspectives of farmers themselves. In 2012, we held six focus groups, each involving between three and 15 farmer participants and marketing association leaders. In these focus groups, we collectively identified key criteria for evaluation of the PAA and PNAE programmes as they related to food sovereignty, as defined by participants, across several dimensions (e.g. social, economic and ecological) and at multiple levels of 
organization (individual, household, community, state and national). Based on farmer input and reflection on the broader principles of food sovereignty found in the academic literature and social movement documents, we developed an indicator framework as part of a semistructured interview questionnaire, which we delivered to a sample of 60 families across seven settlements as part of a linked socio-ecological study (Blesh and Wittman, 2015). Of these, a subset of 39 families had participated in a PAA contract in the past 5 years, and 16 families had also marketed produce through the PNAE programme. The farmer-derived indicators that we measured were as follows:

- Agro-ecological production practices (agrobiodiversity [the number of marketed crops] and soil fertility, reduction of external inputs and access to technical assistance).

- Autonomy and market stability (access to mediated markets, sales to wholesalers, middlemen, farmers markets or other outlets).

- Household income (the total desired income and the proportion of income derived from agricultural activities).

- Household food self-sufficiency (the proportion of household foods from the farm or community).

These interviews and focus groups took place in seven municipalities in Mato Grosso: Campo Verde, Tangará da Serra, Barra do Bugres, Nova Olímpia, Mirrasol d'Oeste, Araputanga and São José dos Quatro Marcos. In these municipalities, farmer participation in the PAA programme ranged from 2.25 per cent in 2006 to 8.55 per cent in 2012 of municipal family farmers, rates that were well above the average for participation in the state of Mato Grosso (1.6-5.0\%) and in Brazil generally (1.9-2.8\%; Table 2). Farmer participants in our study sites were members of three regional family agriculture associations formed to market produce through the PAA and PNAE programmes. The Cooperunião cooperative in Campo Verde was formed in 2009 to collectively market to the PAA and PNAE programmes, involving farmers and association leaders from six land reform settlements. The Associação Regional dos Produtores Agroecológicos (ARPA) in the Cáceres region involves 80 producers from three land reform settlements in Mirrasol d'Oeste, Araputanga and São José do Quatro Marcos. Coopervida was organized through the Rural Worker's Union (STR) in Tangará da Serra, and served participants from land reform settlements in Tangará da Serra, Barra do Bugres and Nova Olímpia.

Finally, we interviewed 26 stakeholders involved in programme support networks (including municipal coordinators of public procurement programmes, coordinators of agrarian reform settlement marketing associations and cooperatives, and representatives from the state and federal government agencies responsible for the PAA and PNAE programmes). We also accessed publically available data on the funding and extension of the PAA and PNAE programmes from official government websites.

\section{RESULTS: ARE MEDIATED MARKETS A PATHWAY TO FOOD SOVEREIGNTY?}

Targeted food procurement programmes such as the PAA and PNAE are examples of a 'systems' approach to agricultural transformation because they are designed to benefit multiple stakeholders in different positions within the food system, including consumers, cooperative distributors and producers themselves, in addition to fostering changes towards ecologically sustainable methods of agricultural production. In this section, we report how programme participation affected several aspects of the food sovereignty framework from the perspective of family farm participants. We focus here on the transition to agro-ecology, farmer autonomy 
and market stability, the coordination of supply and demand, institutional complexity, and household income and food self-sufficiency.

\section{The Transition to Agro-ecology}

Food sovereignty advocates point to the role of global agricultural intensification in land and soil degradation, water pollution, loss of biodiversity and climate change, and advocate for a transition to agro-ecological production practices (Simón Reardon and Pérez 2010; Rosset and Martinez-Torres 2012; Sage 2014). Agro-ecological farming systems incorporate low-input, diversified (and often organic) cultivation methods that aim to conserve biodiversity and ecosystem function, and enhance livelihood provision and community well-being (de Schutter 2011b; Tomich et al. 2011). Within our sampled land reform settlements, movement leaders have promoted agro-ecological practices since the late 1990s. However, the lack of technical assistance and domination of the agro-industrial sector in the farm input market has made the transition to agro-ecology difficult for participants in our study, a challenge faced by many family farmers throughout Brazil. For example, some members of the ARPA cooperative were unable to purchase non-GMO maize seeds within their municipalities, as all of the seeds sold by local agricultural service providers were targeted to large-scale producers.

ARPA producers participate in a farmer-to-farmer agro-ecological certification scheme, which facilitates access to higher prices in procurement contracts. They also had sporadic access to technical assistance from a local environmental NGO, which has promoted integrated pest management practices for pesticide reduction. ARPA participants, in particular, suggested that participation in the PAA programme has helped them transition to more sustainable production practices because of the financial incentives offered. For example, price premiums were utilized to hire additional labour, facilitating the transition to more labourintensive production practices (e.g. hand cultivation rather than utilization of broad-spectrum herbicides).

As remarked by a government land reform supervisor, 'even without [government sponsored] technical assistance, they've organized themselves with appropriate technology' to meet the PAA and PNAE contract demands (interview, INCRA, 2013). Many farmers across the settlements reported in interviews that they now produce vegetables under cover during the rainy season because of the facilitated market opportunity. Prior to participating in the mediated markets, vegetable production was normally only practiced in the dry season. We also found that PAA participation is linked to investments in soil fertility, with PAA contract holders having significantly higher levels of particulate organic matter and soil phosphorous following the application of manure (rather than chemical fertilizers), as compared to neighbouring farmers who were not fulfilling PAA contracts (Blesh and Wittman, 2015).

Agrobiodiversity refers to 'the variety and variability of living organisms that contribute to food and agriculture in the broadest sense, and the knowledge associated with them' (Jackson et al. 2007), with more diverse agricultural systems maintaining higher levels of ecosystem services (Perfecto and Vandermeer 2010; Kremen and Miles 2012). In Mato Grosso, study participants referred to the dominance of the 'monoculture of milk', as milk production was one of the few commodities that provided a reliable income for small-scale farmers in the region. Because local dairy cooperatives pick up milk daily from the farm gate based on an annual contract, the distribution costs of milk production are lower compared to marketing cash crops, which farmers need to arrange to be delivered to a diverse range of markets, or negotiated on an irregular basis with intermediaries. Several of the farmer participants 
Figure 2 Market participation, study participants

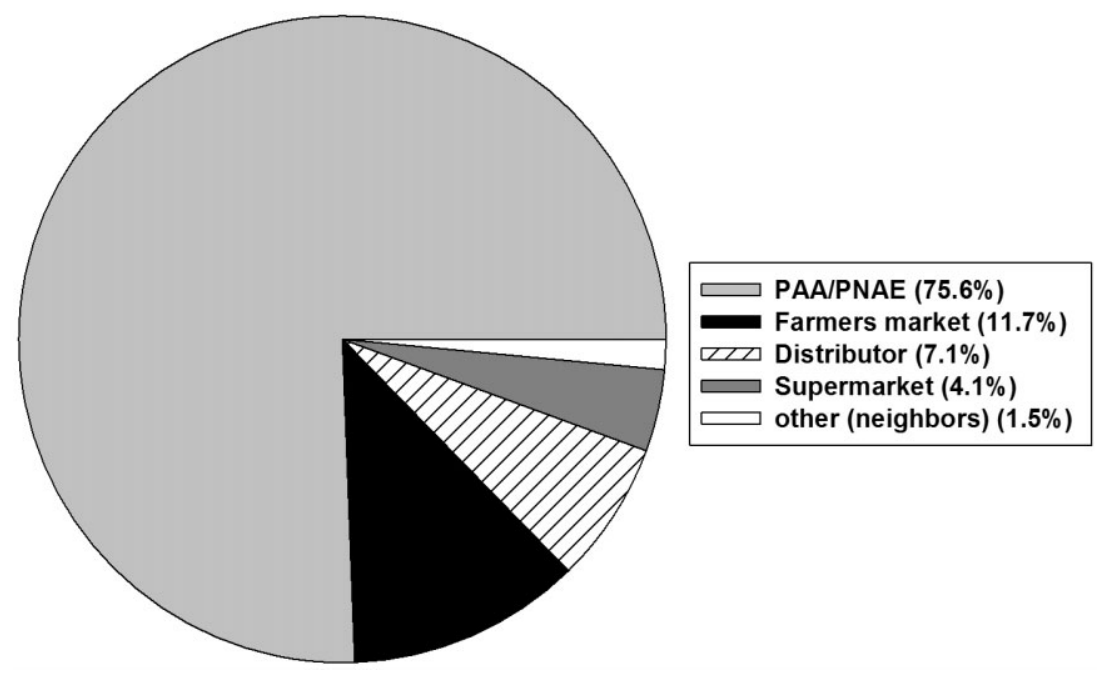

indicated that low labour availability and a higher cost of production were other major barriers to crop diversification, especially in fresh fruit and vegetable production using agroecological methods.

Our study found that participants in the PAA programme had higher levels of on-farm agrobiodiversity (Blesh and Wittman, 2015), which they explained was a response to the demand for an increased variety of products for school feeding programmes. With a guaranteed market and advance contracts that allowed coordinated crop planning, farmers were more willing to invest in shared marketing logistics and cooperative distribution. Expanding beyond milk production and traditional cash crops such as banana, corn and cassava, settlers began to market expanded horticultural varieties. For the farmers selling through PAA/PNAE, on average 75.6 per cent of their production is sold through a mediated market $( \pm 5.3, N=39$ farmers; Figure 2). We found that these PAA/PNAE participants were marketing a much larger range of crops on an annual basis as compared to neighbouring farmers who were not participating in the PAA and PNAE programmes (mean number of crops sold 14 versus 3.7, respectively) (Blesh and Wittman, 2015).

\section{Autonomy and Market Stability}

Marketing is one of the biggest challenges for land reform recipients in Mato Grosso, principally due to challenges with both geography and economies of scale. Settlements tend to be developed at long distances from urban centres, without adequate transportation infrastructure. Marketing generally involves private wholesalers/middlemen who purchase a limited variety of products from individual producers (primarily banana, cassava and milk). Historically, government procurement programmes for food stocks (mainly cereal grains and legumes) treated small-scale farmers equally with large-scale producers, which effectively barred them from participation, as their costs of production were higher due to their lack of access to mechanization and key infrastructure, including roads and processing facilities (interview, CONAB, 2014). The PAA and PNAE restructured and expanded the government 
procurement network beyond dry grains, to include diversified and fresh foods utilized in public food security programmes. This effectively opened up a new opportunity to family farmers, who were able to collectively market horticultural crops grown on smaller plots of land using primarily family labour.

In interviews and focus groups, farmer participants highlighted the importance of 'autonomy' from commodity markets (dominated by soybean in Mato Grosso), which they viewed as controlled by international agribusiness. The focus of the PAA and PNAE programmes on facilitating the production and trade of crops oriented towards domestic food consumption for food security fitted the farmer's conceptualization of food sovereignty. These farmers lacked the scale necessary to compete on commodity markets, which favoured largevolume and/or consistent and regular deliveries as part of large supermarket or export contracts, often at low prices. These settlers' vision of autonomy was congruent with van der Ploeg's (2008) concept of territorial autonomy, in which targeted state support facilitates greater levels of self-determination at the household level and the revitalization of the family farm sector as a social class. Agrarian movements lobbied for the implementation of mediated markets through the PAA and PNAE programmes precisely to support this vision of autonomy, which they argued would enable the production of a multifunctional landscape, social solidarity and economic well-being for the family farm sector (Wittman 2013; Stock et al. 2014). Even though the quantities of food purchased through the PAA programme varied from year to year based on federal funding levels (Table 4), affecting the number of total participants, farmers in our study viewed participation in the PAA and PNAE programmes as favourable as compared to marketing their crops through wholesalers, because they saw the production as directly contributing to local food security, while enjoying fixed prices and reliable contract arrangements. They also spoke of the difficulty of accessing wholesale and supermarket contracts for diversified vegetable production, and saw the PAA and PNAE as a potential solution to their historical marketing difficulties.

\section{Coordinating Supply and Demand}

Even in these mediated market arrangements, we found that one of the most significant challenges for farmer participants and the institutions receiving their deliveries was the coordination of supply and demand. Participants in our study provided deliveries to a broad range of municipal food programmes (Table 5) with distinct food needs and facilities for food preparation.

Table 5. Consumer beneficiaries of PAA programme, study municipalities, 2006-12

\begin{tabular}{lccrcr}
\hline Year & Schools & Youth programmes & Hospitals & Other & Totals \\
\hline 2006 & 15,922 & 385 & 60 & 132 & 16,499 \\
2007 & 26,539 & 1,955 & 0 & 5,546 & 34,040 \\
2008 & $\mathrm{n} / \mathrm{a}$ & $\mathrm{n} / \mathrm{a}$ & $\mathrm{n} / \mathrm{a}$ & $\mathrm{n} / \mathrm{a}$ & $\mathrm{n} / \mathrm{a}$ \\
2009 & 13,527 & 2,361 & 0 & 3,477 & 19,365 \\
2010 & 41,458 & 4,767 & 450 & 6,811 & 53,486 \\
2011 & 33,661 & 2,554 & 450 & 15,748 & 52,413 \\
2012 & 12,181 & 650 & 0 & 19,944 & 32,775 \\
Totals & 143,288 & 12,672 & 960 & 51,658 & 208,578 \\
\hline
\end{tabular}

Source: CONAB-MT Annual Reports, 2006-12. 
The participation of urban food security councils, school boards and rural development councils in overseeing PAA and PNAE contracts in the municipalities was an important vehicle for communication in restructuring both production strategies on the part of the producers and the meal planning strategies on the part of local institutions. On the one hand, it was important for institutional meal programme planners to understand the capacity of local producers to supply the varieties and quantities of foods required by their meal programmes. As one secretary of agriculture remarked, 'the production goes up and down with the rains, but the level of demand doesn't change' (interview, Tangara da Serra Secretary of Agriculture, March 2013). One marketing cooperative leader expressed frustration with the school nutritionist, who had previously refused to make changes in the standardized lunch menus to accommodate seasonal availability of local produce. In response, producer associations met with school nutrition councils to learn about the ingredients for approved school menus, and engaged in production planning to meet those needs. They also engaged with school directors and nutritionists to help them better understand the reality of the local production system. An ARPA member explained:

We wanted to be seen and valued. We had a meeting [with the nutritionists] and prepared lunch, took them on a tour of our vegetable fields, and showed them it was free of pesticides. We had to meet with the nutritionist because they have to sign off on all the (PAA and PNAE) projects that are submitted. (Interview, March 2013)

In a March 2014 focus group that we held with the Mato Grosso Secretary of Education nutritionists in the state capital (Cuiabá), who are responsible for approving all school meal plans across the state, the nutritionists discussed their lack of knowledge about the seasonal and regional availability of particular foods that are commonly grown by the family farm sector. The nutritionists identified this lack of knowledge as a barrier to increased procurement of local foods in school meal programmes.

We conducted an analysis of the fresh food ingredients appearing in the 140 approved school lunch menus provided by the Mato Grosso State Secretary of Agriculture, and compared the most-utilized ingredients with the products that were mainly available from the family farm sector (Table 6). According to the 2006 Agricultural Census (IBGE 2009), the top five most commonly produced commodities in the family farm sector in Mato Grosso are animal products: chicken ( $57 \%$ of family farms, $41 \%$ of total state production), beef (57\% of family farms, $27 \%$ of total state production), eggs ( $27 \%$ of family farms, $40 \%$ of total state production), pork (32\% of family farms, $30 \%$ of total state production) and milk (29\% of family farms, $67 \%$ of total state production). While these items were produced by almost all participants in our study, only a few (one for eggs, four for beef and 14 for chicken) reported marketing these products, and none underwent a formal inspection process. While 74 per cent of our participants marketed milk, and this was also a common school meal ingredient (appearing in 61/140 menus), all milk was marketed through the local milk cooperative to regional milk processing plants, rather than sold through the PAA/PNAE programmes directly to schools. Schools prefer to buy processed (pasteurized) milk in bulk in long-life (UHT) boxes for easy storage, rather than buying milk directly from farmers. Tightened food safety regulations were also cited as a reason for not purchasing directly from farmers.

In the fruit and vegetable sector, we found a disconnect between the most frequently used products in school food systems (rice, beans, onions and garlic, which were sourced from supermarkets and distributors, and generally grown in mechanized systems in southern Brazil) and the foods most commonly grown by family farmers in land reform settlements (cassava, 
Table 6. Institutional demand and family farm production

\begin{tabular}{|c|c|c|}
\hline & $\begin{array}{l}\text { Frequency of appearance } \\
\text { on state-approved menus } \\
\qquad(N=140)\end{array}$ & $\begin{array}{c}\text { Percentage of respondents } \\
\text { that produce item }\end{array}$ \\
\hline \multicolumn{3}{|c|}{ Fresh fruits and vegetables } \\
\hline Onion & 119 & 5.1 \\
\hline Bean & 114 & 33.3 \\
\hline Garlic & 74 & 2.6 \\
\hline Rice & 51 & 20.5 \\
\hline Green onion & 46 & 10.3 \\
\hline Parsley & 39 & 10.3 \\
\hline Tomato & 26 & 56.4 \\
\hline Cassava & 25 & 92.3 \\
\hline Carrot & 20 & 30.8 \\
\hline Corn & 16 & 84.6 \\
\hline Apple & 9 & 0.0 \\
\hline Cabbage & 9 & 2.6 \\
\hline Collard Greens & 8 & 76.9 \\
\hline Banana & 7 & 97.4 \\
\hline Lettuce & 8 & 64.1 \\
\hline Potato & 6 & 0.0 \\
\hline Squash & 4 & 66.7 \\
\hline Papaya & 4 & 35.9 \\
\hline Green bean & 3 & 2.6 \\
\hline Hominy & 3 & 0.0 \\
\hline Orange & 3 & 64.1 \\
\hline Pineapple & 3 & 7.7 \\
\hline Chayote & 2 & 0.0 \\
\hline Okra & 2 & 35.9 \\
\hline \multicolumn{3}{|c|}{ Meat and dairy products } \\
\hline Milk & 61 & 74.4 \\
\hline Egg & 41 & 92.3 \\
\hline Beef & 32 & 10.3 \\
\hline Chicken & 16 & 92.3 \\
\hline Pork & 2 & \\
\hline
\end{tabular}

Source: Original survey data; Mato Grosso Secretary of Education approved school menus.

corn, banana, squash, lettuce, collard greens and oranges). One farmer participant summarized her rationale for their farming and marketing cooperative focusing on fruit and vegetable crops:

It's not viable to produce rice and beans. Rice is extremely difficult to produce. To grow enough to eat, it was all by hand, extremely time consuming and difficult. On a bigger area, it needs machines, which is not realistic in the settlement. It's more viable to increase milk production by 50 liters per month and buy rice and beans. You'll see that much of the things that are important for sustainability/food security are not viable from the point of view of financial sustainability. (Interview, February 2012) 
In addition, interviews with school meal planners indicated that many schools lacked the infrastructure and labour required to process fresh food (especially meat, dairy, fruits and vegetables) provided through family farmer contracts with the PAA and PNAE programmes. One school cook mentioned that she preferred to serve juice made from powdered concentrate rather than juice made from fresh fruit, because it was quicker to prepare. A farmer who had delivered fresh fruit to school one week was disappointed to see it 'rotting under the table' when she made a subsequent delivery. However, small-scale farmers on land reform settlements are limited in their ability to engage in sales of valueadded, processed foods, including meat and dairy, due to the prohibitive cost of upgrading their facilities to meet new heath regulation standards. For example, the Tangará da Serra cooperative stopped producing cheese and cassava flour when the health regulations were tightened, and the ARPA cooperative processing kitchen was closed when the regulations for commercial kitchens were changed to disallow the use of copper pots, in favour of stainless steel. The replacement cost of the kitchen equipment was estimated at US $\$ 30,000$, far out of reach for the cooperative budget. The State Nutrition Coordinator for the PNAE programme also noted the inability of the family farm sector to contribute to the meat/dairy components of the school meal programmes, due to the 'lack of inspection capacity' and the high cost of developing regulated processing facilities (interview, April 2014).

\section{Institutional Complexity and Transaction Costs}

The arugula doesn't wait for approval - it turns yellow.

We have $3 \mathrm{G}$ but no roads.

Logistics is what gets us down.

One of the advantages of the PAA programme for farmer participants had been the ability to substitute products based on availability, but a regulatory change in 2012 made substitutions more difficult. Similarly, product substitution was generally not accepted by schools under PNAE contracts, due to the necessary compliance with nutritionist-approved menus. The PNAE programme was also perceived as having a 'quality standard' that is more strictly enforced than in the PAA, and several school directors commented in interviews that they had turned away deliveries of poor-quality produce coming from the settlements. One municipal agriculture secretary commented that produce from the family agriculture sector in the municipality's only land reform settlement was

Far away, bad roads, bad soil, and low quality goods - bad sizes and color, not a 'commercial market ready product' - but for PAA that was OK. (Tangará da Serra, interview, 19 March 2013)

Small-scale farmers attributed poor product quality to lack of infrastructure, and damage caused by poor road conditions. One farmer participant commented that they lost several deliveries due to the 'produce turning to mush' on the bumpy roads. Another spoke of crops unable to be sold because they had passed their appropriate harvesting date while waiting for contract approval from CONAB, the government purchasing agency for the PAA.

Finally, all interviewed parties referred to the challenges associated with the high transaction costs of the physical delivery of products to schools and social service agencies. In one municipality, the equivalent of 10 days of full-time labour was required for municipal 
employees to coordinate the weekly delivery of PAA and PNAE products from land reform settlements, a cost that was not reflected in the price paid to producers. In another municipality, the local government changed hands and revoked the use of a municipal vehicle that had been on loan to a farmer producer association for product delivery. Both producers and organizers found the uncertainty over delivery and payment a major barrier to participation in both PAA and PNAE contracts. To resolve this issue, both the Coopervida and ARPA regional associations, based in Tangará da Serra and Cáceres, respectively, purchased a delivery vehicle and hired a full-time staff person to develop a production calendar, coordinate pick up and deliveries, and to facilitate payments to individual producers.

While most interview participants - both producers and school meal programme representatives - spoke positively overall about the potential of these facilitated market programmes to improve farmers' livelihoods and support diversification of farming practices, they still faced significant challenges with institutional complexity and transaction costs associated with programme participation. Winning a PNAE supply contract requires participation in a public tender auction and a commitment to supply larger quantities at dates throughout the school year, designated in advance. Although group membership is not required, our respondents found a scale barrier to participation in the PNAE through individual contracts. In practice, PNAE contracts tended to go to larger, more capitalized family farmers, rather than individual farmers from land reform settlements. In response, the Coopervida and ARPA cooperatives participated in PNAE contracts as a group rather than as individuals.

To participate in the PAA, our participants were required to be a member of an association or cooperative, which was viewed by some participants as a positive source of shared knowledge and organizational strategies, especially around production methods, product delivery and contract preparation. However, other settlers felt pressured to join marketing associations that had political aims, with a broader focus than product marketing, and expressed reservations about mixing political advocacy for rural development with product marketing. In response, the Tangará da Serra settlement, for example, was home to two separate marketing associations, one affiliated with the Landless Worker's Movement (MST), which explicitly articulated its PAA participation as a food sovereignty mechanism. The second utilized more neutral language and in effect acted as a local wholesaler. Both associations, however, supported farmers in cropping system diversification and negotiating PAA and PNAE contracts.

The contract process for participation in both the PAA and the PNAE was onerous for resource-poor farmers. For the PAA, group contracts had to be submitted online and payments for deliveries were delivered via direct deposit to an association account in bank branches distant from farming communities. For the PNAE, schools paid individual farmer contracts directly. In both cases, payment was often greatly delayed. In one municipality, the Secretary of Agriculture office provided technical support for contract development and financial administration for participating farmers during the first 3 years of PAA implementation in that municipality, but by 2012 planned to turn this role over to the producer cooperative. Programme regulations and payment arrangements varied from year to year, with no clear mechanism for information transfer to remote rural communities lacking Internet and telephone service. Participants also experienced difficulty with programme and policy overlap - schools receiving food via donation from the PAA were less likely to comply with the PNAE directive to purchase 30 per cent from local farmers, stating (interview, March 2013) 'Why would we purchase the food from PNAE if CONAB is giving it for free?' 


\section{Household Income and Food Self-Sufficiency}

Our study found no significant difference in household income between participants and non-participants in the PAA and PNAE programmes, but interview participants indicated that programme participation made a difference in their household financial planning in terms of reducing reliance on off-farm labour for cash, a key component in focus group discussions of food sovereignty. Only 37.9 per cent of interview participants $(N=29)$ reported achieving their desired level of income through agriculture (average level of desired income $=\mathrm{R} \$ 1457$, about double the minimum wage). On the other hand, focus group discussions and interviews with individual farmers indicated a strong desire to 'grow our own food' as a key component of autonomy and food sovereignty at the household level. We found that there was significant household self-reliance on on-farm production of fruits, vegetables, eggs, pork, chicken, milk, cassava and corn, with cash-based food expenditures for staple foods, mainly for rice, beans and pasta (Blesh and Wittman, 2015). Participants indicated that they sought market integration to supplement on-farm production, to generate cash income for other household expenses.

\section{DISCUSSION AND CONCLUSION}

Food security based on an external trade-oriented paradigm relies on balancing supply and demand through the principle of comparative advantage, with national food self-sufficiency critiqued by dominant institutions as 'cost-ineffective' (Otero et al. 2013). As an agricultural powerhouse with strong trade surpluses but ongoing issues with structural poverty and food insecurity, the transformation of Brazil's agricultural development policy through public procurement programmes linked to rural development has the potential to be a "win-win investment' of limited government funds in environmental, social and economic priority areas (Graeub et al. 2015). By explicitly connecting the specific needs of both the demand (food security and public nutrition programmes) and supply (family farming) sectors, targeted public procurement can support a socially, economically and environmentally resilient rural economy, according to programme participants. Participants in this study highlighted the role of the programme in enabling a transition to crop diversification and other agro-ecological production practices, in risk reduction and improvement in farm financial planning, and in increased access to markets, leading to more reliable incomes, while contributing to food security at the household and community levels.

While the food sovereignty framework has been sometimes characterized as anti-trade and pro-self-reliance (e.g. Hospes 2013; Agarwal 2014), other food sovereignty networks have advocated a fair trade model characterized by transparency, equitable risk and resource sharing, and democratic governance as key pillars of food sovereignty (Windfuhr and Jonsén 2005; Fairbairn 2012). Globally, public procurement budgets range from 6 to 10 per cent of GDP, and historically 'governments have used their purchasing power to achieve important redistributive and developmental goals' (de Schutter 2014, 2). The PAA and PNAE programmes, as mediated market arrangements, represent a potential mechanism for achieving goals and principles related to food sovereignty because they increase transparency and access for both marginalized producers and consumers who have been historically excluded from agricultural markets. The PAA, in particular, supports food sovereignty's 'peasant principle', which focuses on selling surplus from subsistence activities rather than a sole focus on scaling up production specifically to capture market share (van der Ploeg 2014). However, we found that having a guaranteed market through the PAA and PNAE also provided an important 
baseline from which farmers in our sample could scale up and out to other regional market opportunities. To this end, differentiated or 'mediated' markets recognize family farmers as a distinct category of producers with specific needs for targeted market integration, and are thus able bridge rural and urban needs for social protection (Schmidt et al. 2015).

In practice, however, the potential for these programmes to scale up food sovereignty in Brazil is limited, at least as currently designed and budgeted. Programme uptake is relatively small, reaching less than 10 per cent of family farmers at the national level. One of the goals of the PAA is to 'increase production' in the family farm sector. Although it is clear that for our participants the composition of crops is changing to higher-value and diversified rotations, with greater investments in soil fertility, is not clear from this study whether total volumes of production are being increased, or if participants are instead selling surplus that might have otherwise been consumed at the household level or fed to animals. Many more highly capitalized family farmers in Brazil who do not participate in mediated market initiatives are already readily accessing consumer markets, and others working independently of producer associations and cooperatives choose not to participate because of the logistics involved. Thus, mediated markets are more likely to make a difference for the most resourcepoor sector of Brazil's family farm base - those likely to be found in agrarian reform settlements, where market access is incipient and not integrated into larger and/or more distant supply chains.

In Mato Grosso, all funding for the PAA between 2003 and 2012 was financed through the Ministry of Social Development, with no funding for the PAA stream coming from the Ministry of Agrarian Development, emphasizing its structural focus on social protection, rather than rural economic development. Study participants also pointed out that unlike the PNAE, the PAA is 'a program, not a policy', meaning that the programme and its budget are subject to change from year to year, depending on budgetary priorities at the federal level. Conversely, the PNAE's legal commitment to purchasing 30 per cent of school meal inputs from the family farm sector is more difficult to change. However, the programme requirements of the PNAE make it less accessible to the more marginalized producers found in rural land reform settlements, with more limited access to reliable processing infrastructure and transportation. Overall, programme participation is limited by low levels of public investment in distribution infrastructure, institutional complexity and high transaction costs for producers and the government programmes themselves, as well as budgetary caps on participation. Even with the increased budget of $\$$ R 1.1 billion for the 2013/14 fiscal year, more than double what was spent in 2012, the PNAE purchasing programme targeting the family sector would have a maximum participation of 55,000 farmers, under 2 per cent of all family farms in Brazil.

Finally, the PNAE programme, in particular, has demands that the resource-poor farmers in our study cannot meet - staples such as rice and beans, as well as meat and dairy products, require economies of scale and processing and inspection facilities that are out of reach for the poorest sector of family farmers, without significant institutional support. Our analysis highlights a contradiction between social realities (the desire for a regular delivery of highquality local food throughout the year) and biophysical realities (the difficulty of producing fruits and vegetables in the rainy season in this region, and of ensuring regular delivery at any time of the year due to road conditions and settlement locations). In this sense, a better understanding of both the production capacity of resource-poor farmers with limited access to land, and seasonality constraints to the availability of popular menu items, would facilitate coordinating supply and demand with food purchasers and nutrition advisors in public institutions. The average farm size for our research participants was 30 hectares, compared to the 
average farm size in Mato Grosso of 430 hectares, and land inequality in this state is among the worst in Brazil. Expanding land distribution efforts to support diversified production systems at a slightly larger scale, as well as expanding access to technical assistance, would probably also facilitate greater connection between local producers and public institutions.

In conclusion, our participatory assessment of public food procurement programmes as a pathway towards increased food sovereignty in Mato Grosso highlighted both opportunities and challenges. We found that resource-poor farmers in Mato Grosso who participate in public procurement positively evaluate the programme's influence on both their transition to agro-ecology and their household well-being. Interviews with actors along the food system revealed the potential for these programmes to achieve goals related to food-system sustainability and social equity. We view this case as a model of innovation (within a highly unsustainable agricultural matrix) that can inform scaling up of food sovereignty. However, much needs to be done to untangle critical bottlenecks in infrastructure and transaction costs before public food procurement programmes can be considered a viable and scalable solution to global food crises.

\section{REFERENCES}

Agarwal, B., 2014. 'Food Sovereignty, Food Security and Democratic Choice: Critical Contradictions, Difficult Conciliations'. Journal of Peasant Studies, 41 (6): 1247-68.

Alderman, H. and D. Bundy, 2012. 'School Feeding Programs and Development: Are We Framing the Question Correctly?' The World Bank Research Observer, 27 (2): 204-21.

Anderson, M.D., 2008. 'Rights-Based Food Systems and the Goals of Food Systems Reform'. Agriculture and Human Values, 25 (4): 593-608.

Ashe, L.M. and R. Sonnino, 2013. 'At the Crossroads: New Paradigms of Food Security, Public Health Nutrition and School Food'. Public Health Nutrition, 16 (6): 1020-7.

Bagdonis, J.M., C.C. Hinrichs and K.A. Schafft, 2008. 'The Emergence and Framing of Farm-to-School Initiatives: Civic Engagement, Health and Local Agriculture'. Agriculture and Human Values, 26 (1-2): 107-19.

Bello, W., 2008. 'How to Manufacture a Global Food Crisis'. Development, 51 (4): 450-5.

Bello, W.F., 2009. The Food Wars. New York: Verso.

Blesh, J. and H. Wittman, 2015. "Brasilience": Assessing Resilience on Land Reform Settlement Farms in the Brazilian Cerrado'. Human Ecology. doi: 10.1007/s10745-015-9770-0.

Borras, S.M. Jr and J.C. Franco, 2010a. 'Food Sovereignty and Redistributive Land Policies: Exploring Linkages, Identifying Challenges'. In Food Sovereignty: Reconnecting Food, Nature and Community (eds H. Wittman, A.A. Desmarais and N. Wiebe), 106-19. Halifax, NS: Fernwood.

Borras, S.M. Jr and J.C. Franco, 2010b. 'Contemporary Discourses and Contestations around Pro-Poor Land Policies and Land Governance'. Journal of Agrarian Change 10 (1): 1-32.

Buckley, J., D.S. Conner, C. Matts and M.W. Hamm, 2013. 'Social Relationships and Farm-to-Institution Initiatives: Complexity and Scale in Local Food Systems'. Journal of Hunger \& Environmental Nutrition, 8 (4): 397-412.

Bundy, D.A., L.J. Drake and C. Burbano, 2013. 'School Food, Politics and Child Health'. Public Health Nutrition, 16 (6): 1012-19.

Bundy, D.A.P., 2011. Rethinking School Health: a Key Component of Education for All. Washington, DC: World Bank.

Bundy, D.A.P., C. Burbano, M. Grosh, A. Gelli, M. Jukes and L. Drake, 2009. Rethinking School Feeding: Social Safety Nets, Child Development, and the Education Sector. Washington, DC: World Bank.

Cassidy, E.S., P.C. West, J.S. Gerber and J.A. Foley, 2013. 'Redefining Agricultural Yields: from Tonnes to People Nourished per Hectare'. Environmental Research Letters, 8 (3): 034015.

Chaifetz, A. and P. Jagger, 2014. '40 Years of Dialogue on Food Sovereignty: a Review and a Look Ahead'. Global Food Security, 3 (2): 85-91.

Chmielewska, D., 2011. The Food Security Policy Context in Brazil. Brasilia: International Policy Centre for Inclusive Growth, UNDP.

CNSAN (Conferência Nacional de Segurança Alimentar e Nutricional), 2010. 'Linha do tempo da segurança alimentar e nutricional no Brasil'. In $4^{a}$ Conferência Nacional de Segurança Alimentar e Nutricional, 7 a 10 de novembro de 2011 - Salvador - BA, Manual Orientador, 1-44. 
CONAB (Companhia Nacional de Abastecimento), 2006. Programa de Aquisição de Alimentos/PAA - renda para quem produz e comida na mesa de quem precisa! Brasilia: CONAB.

Conner, D.S., G. Abate, T. Liquori, M.W. Hamm and H.C. Peterson, 2010. 'Prospects for More Healthful, Local, and Sustainably Produced Food in School Meals'. Journal of Hunger \& Environmental Nutrition, 5 (4): $416-33$.

Conner, D.S., B. King, C. Koliba, J. Kolodinsky and A. Trubek, 2011. 'Mapping Farm-to-School Networks Implications for Research and Practice'. Journal of Hunger \& Environmental Nutrition, 6 (2): 133-52.

da Silva, J.G., M.E. Del Grossi and C.G. de França, eds, 2011. The Fome Zero (Zero Hunger) Program: The Brazilian Experience. Brasilia: MDA/FAO.

DATALUTA, 2012. Brasil - Relatorio DATALUTA 2011. Presidente Prudente: NERA - Núcleo de Estudos, Pesquisas e Projetos de Reforma Agrária - FCT/UNESP.

de Arruda Saron, F. and A.N. Hespanhol, 2012. 'O PRONAF e as políticas de desenvolvimento rural no Brasil: o desafio da (re)construção das políticas de apoio a agricultura familiar’. Geo UERJ, 14 (24): 656-83.

de França, C.G., M.E. Del Grossi and V.P.M. de A. Marques, 2009. O Censo Agropecuário e a Agricultura Familiar no Brasil. Brasília: Ministerio de Desenvolvimento Agrícola (MDA)/Núcleo de Estudos Agrários e Desenvolvimento Rural (NEAD).

de Schutter, O., 2010. Countries Tackling Hunger with a Right to Food Approach: Significant Progress in Implementing the Right to Food at National Scale in Africa, Latin America and South Asia. Geneva: United Nations.

de Schutter, O., 2011a. Towards More Equitable Value Chains: Alternative Business Models in Support of the Right to Food: Report Presented at the 66th Session of the United Nations General Assembly [A/66/262]. UN Special Rapporteur on the Right to Food. Geneva: United Nations.

de Schutter, O., 2011b. Agroecology and the Right to Food: Report Submitted by the Special Rapporteur on the Right to Food, 16th edn. New York: United Nations Human Rights Council.

de Schutter, O., 2014. The Power of Procurement: Public Purchasing in the Service of Realizing the Right to Food. Rome: UN Special Rapporteur on the Right to Food, Briefing Note No. 08.

Devereux, S., R. Sabates-Wheeler and A.P. Martinez, 2010. Home Grown School Feeding and Social Protection. HGFS Working Paper Series, No. 5.

Dorward, A., 2013. 'Agricultural Labour Productivity, Food Prices and Sustainable Development Impacts and Indicators'. Food Policy, 39 (C): 40-50.

Espejo, F., C. Burbano and E. Galliano, 2009. Home-Grown School Feeding: a Framework to Link School Feeding with Local Agricultural Production. Rome: United Nations World Food Programme.

Fairbairn, M., 2012. 'Framing Transformation: the Counter-Hegemonic Potential of Food Sovereignty in the US Context'. Agriculture and Human Values, 29 (2): 217-30.

Fernandes, B.M., 2014. 'Re-peasantization, Resistance and Subordination: the Struggle for Land and Agrarian Reform in Brazil'. Agrarian South: Journal of Political Economy, 2 (3): 269-89.

Fernandes, B.M., C.A. Welch and E.C. Gonçalves, 2012. Land Governance in Brazil: a Geo-historical Review. Rome: International Land Coalition.

Finan, T.J., A. Rashid, B. Woel, S. Arunga, S. Rutere and M. Muindi, 2010. Impact Evaluation of WFP School Feeding Programmes in Kenya (1999-2008): a Mixed-Methods Approach. Rome: United Nations World Food Programme.

Gentilini, U. and S.W. Omamo, 2011. 'Social Protection 2.0: Exploring Issues, Evidence and Debates in a Globalizing World'. Food Policy, 36 (3): 329-40.

Gottlieb, R., M. Vallianatos and A. Joshi, 2009. 'Farms to Schools: Promoting Urban Health, Combating Sprawl, and Advancing Community Food Systems (Southern California)'. In Breakthrough Communities: Sustainability and Justice in the Next American Metropolis, eds M.P. Pavel and M.P. Pavel, 285-302. Cambridge, MA: The MIT Press.

Graeub, B.E., M.J. Chappell, H. Wittman, S. Ledermann, R. Bezner Kerr and B. Gemmill-Herren, 2015. 'The State of Family Farms in the World'. World Development: 1-66.

Grisa, C., C.J. Schmitt, L.F. Mattei, R.S. Maluf and S.P. Leite, 2011. 'Contribuições do Programa de Aquisição de Alimentos à segurança alimentar e nutricional e à criação de mercados para a agricultura familiar’. Agriculturas, 8 : 1-8.

Hospes, O., 2013. 'Food Sovereignty: the Debate, the Deadlock, and a Suggested Detour'. Agriculture and Human Values, 31 (1): 119-30.

IBGE, 2009. Censo Agropecuário 2006: Brasil, grandes regiões e Unidades da Federação. Rio de Janeiro: IBGE.

INCRA and MDA, 2012. Projetos de reforma agrária conforme fases de implementação. SIPRA/SDM. Ministerio de Desenvolvimento Agrícola (MDA)/Instituto Nacional de Colonização e Reforma Agrária, No. Rel_0227.

Izumi, B.T., D.W. Wright and M.W. Hamm, 2010. 'Market Diversification and Social Benefits: Motivations of Farmers Participating in Farm to School Programs'. Journal of Rural Studies, 26 (4): 374-82.

Jackson, L.E., U. Pascual, L. Brussaard, P.C. De Ruiter and K.S. Bawa, 2007. 'Biodiversity in Agricultural Landscapes: Investing without Losing Interest'. Agriculture, Ecosystems \& Environment, 121 (3): 193-5. 


\section{Hannah Wittman and Jennifer Blesh}

Jansen, K., 2015. 'The Debate on Food Sovereignty Theory: Agrarian Capitalism, Dispossession and Agroecology'. Journal of Peasant Studies, 42 (1): 213-32.

Joshi, A., A.M. Azuma and G. Feenstra, 2008. 'Do Farm-to-School Programs Make a Difference? Findings and Future Research Needs'. Journal of Hunger \& Environmental Nutrition, 3 (2-3): 229-46.

Kirwan, J. and C. Foster, 2007. 'Public Sector Food Procurement in the United Kingdom: Examining the Creation of an "Alternative" and Localized Network in Cornwall'. In Alternative Food Geographies: Representation and Practice, eds D. Maye, L. Holloway and M. Kneafsey, 185-202. Oxford: Elsevier.

Kremen, C. and A. Miles, 2012. 'Ecosystem Services in Biologically Diversified versus Conventional Farming Systems: Benefits, Externalities, and Trade-Offs'. Ecology and Society, 17 (4): 40.

Lang, T., 2010. 'Crisis? What crisis? The Normality of the Current Food Crisis'. Journal of Agrarian Change, 10 (1): 87-97.

Lang, T., D. Barling and M. Caraher, 2009. Food Policy: Integrating Health, Environment and Society. Oxford: Oxford University Press.

McKay, B., R. Nehring and M. Walsh-Dilley, 2014. "The "State" of Food Sovereignty in Latin America: Political Projects and Alternative Pathways in Venezuela, Ecuador and Bolivia'. Journal of Peasant Studies, 41 (6): 1175-200.

McMichael, P., 2003. 'Food Security and Social Reproduction: Issues and Contradictions'. In Power, Production, and Social Reproduction, eds I. Bakker and S. Gill, 169-89 London: Palgrave Macmillan.

McMichael, P., 2014. 'Historicizing Food Sovereignty'. Journal of Peasant Studies, 41 (6): 933-57.

Martinez-Torres, M.E. and P.M. Rosset, 2010. 'La Via Campesina: the Birth and Evolution of a Transnational Social Movement'. Journal of Peasant Studies, 37 (1): 149-75.

Masset, E. and A. Gelli, 2013. 'Improving Community Development by Linking Agriculture, Nutrition and Education: Design of a Randomised Trial of "Home-Grown” School Feeding in Mali'. Trials, 14: 1-23.

Matts, C., D.S. Conner, C. Fisher, S. Tyler and M.W. Hamm, 2015. 'Farmer Perspectives of Farm to Institution in Michigan: 2012 Survey Results of Vegetable Farmers'. Renewable Agriculture and Food Systems, 1-12.

Medaets, J.P., K. Pettan and M. Takagi, 2004. Family Farming and Food Security in Brazil. OECD Global Forum on Agriculture: Designing and Implementing Pro-Poor Agricultural Policies. Brasília: Ministério de Desenvolvimento Agrária (MDA).

Mendoça Leão, M., 2012. Effective Public Policies and Active Citizenship: Brazil's Experience of Building a Food and Nutrition Security System. Brasília: ABRANDH.

MAPA (Ministério de Agricultura Pecuária e Abastecimento), 2013. Plano Agrícola e Pecuário 2013/2014. Brasilia: MAPA.

MDA (Ministério de Desenvolvimento Agrário), 2013. 'Plano Safra da Agricultural Familiar 2013/2014', http:// portal.mda.gov.br/plano-safra-2013/ (accessed April 2014).

Nyéléni Forum for Food Sovereignty, 2007. Declaration of the Forum for Food Sovereignty. Selingué, Mali.

Otero, G., G. Pechlaner and E.C. Gurcan, 2013. 'The Political Economy of "Food Security" and Trade: Uneven and Combined Dependency'. Rural Sociology, 78 (3): 263-89.

Otsuki, K., 2011. 'Sustainable Partnerships for a Green Economy: a Case Study of Public Procurement for HomeGrown School Feeding'. Natural Resources Forum, 35 (3): 213-22.

Otsuki, K., 2014. 'Social Economy of Quality Food'. International Journal of Social Economics, 41 (3): $233-43$.

Otsuki, K. and A. Arce, 2006. Brazil - A Desk Review of the National School Feeding Programme. Rome: United Nations World Food Programme.

Patel, R., 2009. 'Food Sovereignty'. Journal of Peasant Studies, 36 (3): 663-73.

Peraci, A.S. and G.A. Bittencourt, 2011. 'Family Farming and Price Guarantee Programs in Brazil: the Food Acquisition Program (PAA)'. In Fome Zero: The Brazilian Experience, eds J.G. da Silva, C.G. de França and M.E. Del Grossi, 193-224. Brasilia: MDA/FAO.

Perfecto, I. and J.H. Vandermeer, 2010. 'The Agroecological Matrix as Alternative to the Land-Sparing/Agriculture Intensification Model'. Proceedings of the National Academy of Sciences, 107 (13): 5786-91.

Quaye, W., G. Essegbey, G. Frempong and G. Ruivenkamp, 2013. 'Understanding the Concept of Food Sovereignty Using the Ghana School Feeding Programme (GSFP)'. International Review of Sociology, 20 (3): 427-44.

Quaye, W., G. Frempong, J.P. Jongerden and G.T.P. Ruivenkamp, 2009. 'Exploring Possibilities to Enhance Food Sovereignty within the Cowpea Production-Consumption Network in Northern Ghana'. Journal of Human Ecology, 28 (2): 1-10.

Rocha, C., 2007. 'Food Insecurity as Market Failure: a Contribution from Economics'. Journal of Hunger \& Environmental Nutrition, 1 (4): 5-22.

Rocha, C., 2009. 'Developments in National Policies for Food and Nutrition Security in Brazil'. Development Policy Review, 27 (1): 51-66. 
Rocha, C., L. Burlandy and R. Maluf, 2012. 'Small Farms and Sustainable Rural Development for Food Security: the Brazilian Experience'. Development Southern Africa, 29 (4): 519-29.

Rosset, P., 2006. Food Is Different: Why We Must Get the WTO Out of Agriculture. London: Zed Books.

Rosset, P.M. and M.E. Martinez-Torres, 2012. 'Rural Social Movements and Agroecology: Context, Theory, and Process'. Ecology and Society, 17 (3): 17.

Sage, C., 2014. 'The Transition Movement and Food Sovereignty: From Local Resilience to Global Engagement in Food System Transformation'. Journal of Consumer Culture, 14 (2): 254-75.

Schmidt, C., R. Maluf and W. Belik, 2015. 'Family Farming, Institutional Markets and Innovations in Public Policy: Food and Nutritional Security as a Driver for Governmental Intervention'. In Rural Development and the Construction of New Markets, eds P. Hebinck, J.D. van der Ploeg and S. Schneider, 61-78. Abingdon: Routledge.

Schneider, S., S. Shiki and W. Belik, 2010. 'Rural Development in Brazil: Overcoming Inequalities and Building New Markets'. Rivista di Economia Agraria, LXV (2): 225-59.

Sidaner, E., D. Balaban and L. Burlandy, 2013. 'The Brazilian School Feeding Programme: an Example of an Integrated Programme in Support of Food and Nutrition Security'. Public Health Nutrition, 16 (6): 989-94.

Simón Reardon, J.A. and R.A. Pérez, 2010. 'Agroecology and the Development of Indicators of Food Sovereignty in Cuban Food Systems'. Journal of Sustainable Agriculture, 34 (8): 907-22.

Soares, F.V., R. Nehring, R.B. Schwengber, C.G. Rodrigues, G. Lambais, D.S. Balaban, C. Jones and A. Galante, 2013. Structured Demand and Smallholder Farmers in Brazil: the Case of PAA and PNAE. International Policy Centre for Inclusive Growth (IPC-IG), UNDP.

Sonnino, R., 2013. 'Escaping the Local Trap: Insights on Re-localization from School Food Reform'. Journal of Environmental Policy \& Planning, 12 (1): 23-40.

Sonnino, R., C.L. Torres and S. Schneider, 2014. 'Reflexive Governance for Food Security: the Example of School Feeding in Brazil'. Journal of Rural Studies, 36 (C): 1-12.

Stock, P.V., J. Forney, S.B. Emery and H. Wittman, 2014. 'Neoliberal Natures on the Farm: Farmer Autonomy and Cooperation in Comparative Perspective'. Journal of Rural Studies, 36 (C): 411-22.

Sumberg, J. and R. Sabates-Wheeler, 2011. 'Linking Agricultural Development to School Feeding in Sub-Saharan Africa: Theoretical Perspectives'. Food Policy, 36 (3): 341-9.

Thompson, O.M., M.P. Twomey, M.A. Hemphill, K. Keene, N. Seibert, D.J. Harrison and K.B. Stewart, 2014. 'Farm to School Program Participation: an Emerging Market for Small or Limited-Resource Farmers?' Journal of Hunger \& Environmental Nutrition, 9 (1): 33-47.

Tomich, T.P., S. Brodt, H. Ferris, R. Galt, W.R. Horwath, E. Kebreab, J.H.J. Leveau, D. Liptzin, M. Lubell, P. Merel, R. Michelmore, T. Rosenstock, K. Scow, J. Six, N. Williams and L. Yang, 2011. 'Agroecology: A Review from a Global-Change Perspective'. Annual Review of Environment \& Resources, 36 (1): 193-222.

van der Ploeg, J.D., 2008. The New Peasantries: Struggles for Autonomy and Sustainability in an Era of Empire and Globalization. London: Earthscan.

van der Ploeg, J.D., 2014. 'Peasant-Driven Agricultural Growth and Food Sovereignty'. Journal of Peasant Studies, 41: 999-1030.

Vieira, L.M. and S. Galdino, 2004. Pantanal: risco de contaminação por biocidas. Corumbá: Embrapa Pantanal.

Windfuhr, M. and J. Jonsén, 2005. Food Sovereignty: Towards Democracy in Localized Food Systems. Bourton-onDunsmore, UK: FIAN-International; ITDG Publishing.

Wittman, H., 2009. 'Reframing Agrarian Citizenship: Land, Life and Power in Brazil'. Journal of Rural Studies, 25: 120-30.

Wittman, H., 2010. ;Agrarian Reform and the Environment: Fostering Ecological Citizenship in Mato Grosso, Brazil;. Canadian Journal of Development Studies, 29 (3): 281-98.

Wittman, H., 2011. 'Food Sovereignty: A New Rights Framework for Food and Nature?' Environment and Society: Advances in Research, 2 (1): 87-105.

Wittman, H., 2013. 'Feeding the Nation while Mobilizing the Planet? La Vía Campesina, Food Sovereignty, and Transnational Movements in Brazil'. In Transnational Activism in Latin America: Bridging the Divide, ed. E. Silva, 161-85. New York: Routledge.

Wolford, W., 2007. 'Land Reform in the Time of Neoliberalism: a Many-Splendored Thing'. Antipode, 39 (3): $550-70$.

Wolford, W., 2010. This Land Is Ours Now: Social Mobilization and the Meanings of Land in Brazil. Durham, NC: Duke University Press. 